\title{
Pelatihan Pemanfaatan Aplikasi Point of Sale Berbasis Mobile Pencatatan Transaksi Penjualan UKM Tunjung Mekar
}

\author{
${ }^{1}$ Yohanes Priyo Atmojo, ${ }^{2}$ Ida Bagus Suradarma, ${ }^{3}$ I Made Saka Winaya \\ Institut Teknologi dan Bisnis STIKOM Bali \\ Email: 1'yohanes@stikom-bali.ac.id, ${ }^{2}$ suradarma@stikom-bali.ac.id, ${ }^{3}$ sulisw504@gmail.com
}

\begin{abstract}
ABSTRAK
Ukiran kaca dan kayu merupakan jenis usaha kerajinan masyarakat lokal di Bali. Salah satunya adalah Usaha Mikro Industri (UKM) Tunjung Mekar yang bergerak di usaha perajin kayu dan kaca mulai tahun 2010. Kendala yang dihadapi oleh UKM ini adalah proses administratif pencatatan transaksi penjualan. Pencatatan transaksi penjualan tersimpan dalam bentuk catatan kertas dan bukti bayar (kuitansi), yang secara fisik mudah rusak dan hilang. Untuk menangani permasalahan pencatatan transaksi penjualan di UKM maka diusulkan kegiatan pelatihan pemanfaatan aplikasi Point of Sale $(P o S)$ berbasis mobile. Pembuatan aplikasi $P o S$ yang diusulkan sebagai solusi permasalahan UKM disesuaikan dengan kebutuhan yang dimasukkan ke dalam fitur aplikasi. Fitur Aplikasi $P o S$ antara lain: fitur kasir untuk penjualan, fitur laporan untuk pelaporan transaksi, fitur tambah barang untuk menambahkan produk UKM, dan fitur pengeluaran untuk pencatatan pengeluaran UKM. Kegiatan ini bertujuan untuk memberikan pelatihan pemanfaatan aplikasi $P o S$ dengan harapan setiap transaksi penjualan dan pengeluaran operasional UKM dapat tercatat dan terarsip dengan baik, sehingga UKM dapat mengetahui alur keuangan UKM dan mampu memberikan gambaran keadaan keuangan untuk pengembangan usaha. Hasilnya adalah sebuah produk tepat guna yaitu aplikasi $P o S$ dan kemampuan penggunaan $P o S$ padaUKM Tunjung Mekar dengan indikasi penguasaan oleh peserta sebesar 82.5\%.
\end{abstract}

Kata kunci : $P o S$, ukiran kaca, ukiran kayu, aplikasi mobile.

\section{ABSTRACT}

Glass and wood carving is a type of handicraft business in the local community in Bali. One of them is the Tunjung Mekar Micro Industry (UKM), which engages in the wood and glass craftsman business in 2010. The obstacle faced by these UKM is the administrative process of recording sales transactions. Records of sales transactions are store in the form of paper records and proof of payment (receipts), which are physically easily damaged and lost. To handle the problem of recording sales transactions in UKM, it is suggested that training activities on the use of mobile-based Point of Sale (PoS) applications. The creation of a PoS application proPoSed as a solution to UKM problems is tailor to the needs incorporated into the application's features. PoS Application Features include cashier features for sales, report features for transaction reporting, feature added goods to add SME products, and expense features for recording SME expenses. This activity aims to provide training on the use of PoS applications in the hope that each UKM sales transaction and operational costs can be recorded and archived correctly, so that UKM can find out the financial flow of UKM and can provide an overview of the financial situation for business development. The result is a useful product, PoS application and the ability to use PoS in UKM Tunjung Mekar with an indication of $82.5 \%$ mastery by the participants. 
Key words: PoS, glass carving, wood carving, mobile application.

\section{PENDAHULUAN}

Perkembangan industri kerajinan handmade di kawasan Bali berkembang dengan pesat. Banyak UKM yang berkembang, sejalan dengan visi pemerintah Provinsi Bali untuk mengembangkan industri kerajinan lokal (Sunariani, 2017). Hal ini dapat dilihat di beberapa tempat yang mulai bermunculan industri kerajinan rumahan yang mulai membuka usahanya, namun belum banyak begitu dikenal oleh masyarakat luas. Bali yang dikenal sebagai kawasan pariwisata, menuntut adanya UKM kerajinan lokal yang mampu berkreasi dan berinovatif dalam produk usahanya. Salah satu inovasi di bidang UKM adalah pemanfaatan limbah kayu dan limbah kaca yang diolah menjadi produk yang memiliki nilai estetika dan memiliki nilai jual yang tinggi. (Abdurrahman, 2013), (Abednego, 2017), (Tamara, 2016). UKM perajin kaca yang dimaksud adalah perajin yang membuat aquarium dengan bahan baku kaca dan berinovasi dengan bahan baku kayu yang disebut sebagai ukiran kaca dan kayu. Ini menjadi daya peluang usaha yang sangat berpotensi dalam pangsa pasar karena menjadi daya tarik bagi hotel atau villa dan memiliki nilai penjualan yang pasti.

UKM yang dijadikan mitra dalam program pengabdian masyarakat adalah perajin kaca di kawasan Tegallalang daerah Gianyar yang telah memulai usahanya tahun 2010. Proses produksi terdiri dari 10 - 20 orang pekerja (termasuk pemilik dan keluarga). Pekerja lepas yang dibutuhkan sekitar 10 - 15 orang. Proses produksi dilakukan di rumah pemilik usaha yang berlamat di Jl. Tegallalang Kecamatan Tegallalang, Kabupaten Gianyar - Bali. Pemasaran dilakukan dengan memasarkan produk usaha pada beberapa art shop. Produk yang dihasilkan antara lain adalah gelas kaca, aquarium hias (wood glass) dan vas bunga. Bahan - bahan produksi yang digunakan oleh usaha Tunjung Mekar didapatkan dari dari pengepul kaca di kawasan sekitar dan bahan kayu didapatkan dari daerah Gianyar. Jumlah produksi dari UKM Tunjung Mekar dalam satu bulan untuk jenis aquarium hias (wood glass) mencapai 50 - 150 buah, gelas 300 buah, vas bunga 100 - 150 buah. Harga jual produk, bergantung pada ukuran yaitu gelas kaca standar Rp. 30.000 s/d Rp. 50.000, vas bunga Rp. 40.000 s/d 150.000 dan aquarium hias Rp. $1.000 .000 \mathrm{~s} / \mathrm{d} \mathrm{Rp}$. 3.000.000.

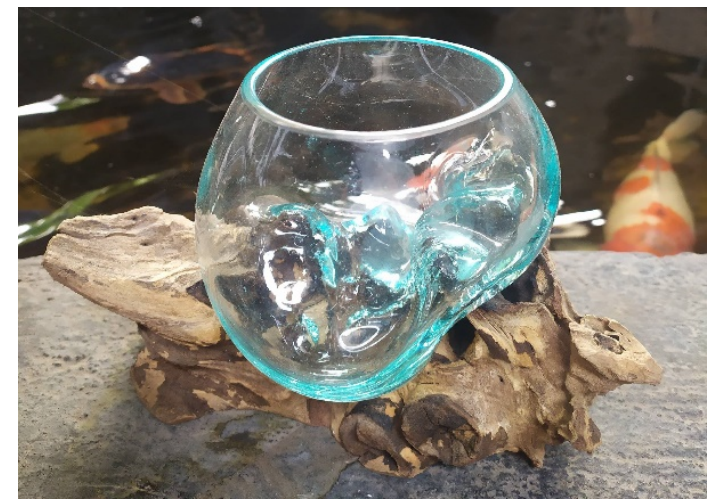

Gambar 1 Produk UKM Tunjung Mekar

Pada proses produksi UKM Tunjung Mekar dilakukan secara manual yaitu dengan tenaga manusia dan menggunakan peralatan sederhana. Peralatan yang digunakan adalah seperti tang, japit besi, tongkat berbahan baja, oven besar (sebagai pembakaran bahan kaca dan pencair kaca) gunting besi, kuas dan peralatan kecil lainnya. Untuk proses pengerjaan produk, pemilik usaha atas nama I Gede Sumada ikut mengerjakan bersama keluarga, dan ikut mengawasi penjualan di lokasi usaha.

Permasalahan yang dihadapi oleh UKM Tunjung Mekar adalah masalah pencatatan transaksi penjualan. Permasalahan yang dimaksud adalah proses administratif atau pencatatan alur keuangan pada UKM, yaitu antara pencatatan penjualan dan pengeluaran operasional. Saat ini, pencatatan transaksi 
penjualan tersimpan dalam bentuk catatan kertas dan bukti bayar (kuitansi), yang secara fisik mudah rusak dan mudah hilang. Pencatatan pengeluaran sebagai biaya operasional usaha juga tidak tercatat, dan adanya penggabungan antara pengeluaran usaha dan pengeluaran pribadi. Hal ini membuat pemilik menjadi susah untuk mengembangkan usaha karena tidak ada pencatatan transaksi yang konsisten dan bisa diakses langsung secara cepat.

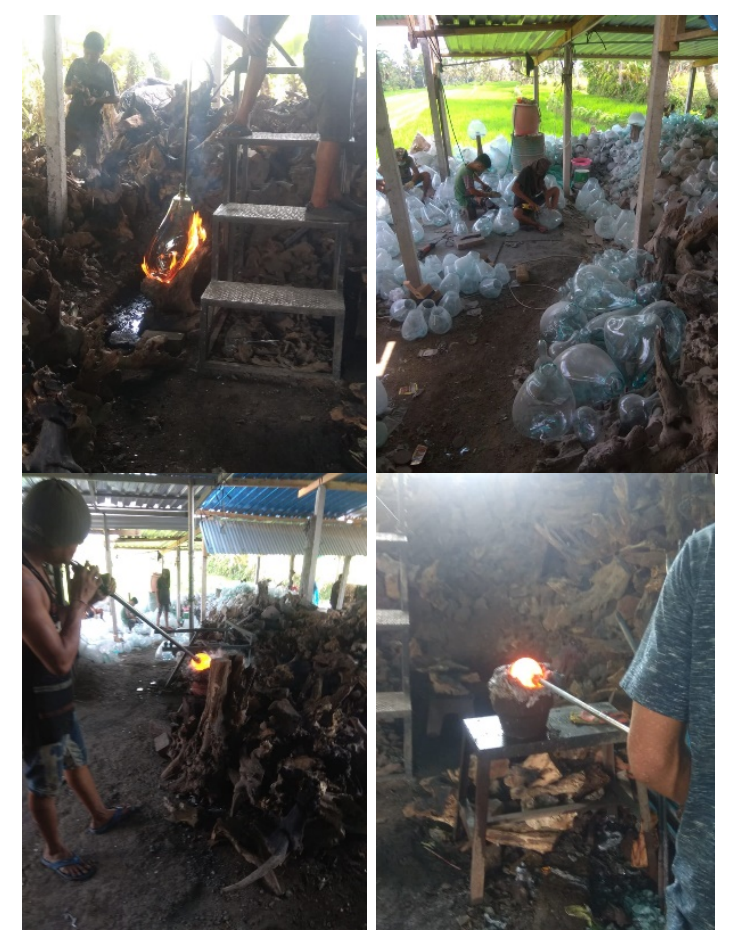

Gambar 2 Proses Produksi UKM Tunjung Mekar

Untuk menentukan permasalahan yang dihadapi oleh mitra UKM, telah dilakukan analisis permasalahan dan solusi yang ditunjukkan pada Tabel 1 .

Tabel 1. Analisis Situasi

\begin{tabular}{|c|c|c|c|}
\hline No & Bidang & Permasalahan & Solusi \\
\hline 1 & $\begin{array}{l}\text { Administ } \\
\text { rasi } \\
\text { keuangan }\end{array}$ & $\begin{array}{l}\text { - Pencatatan masih } \\
\text { manual dan mudah } \\
\text { rusak atau hilang. } \\
\text { - Pengeluaran } \\
\text { operasional tidak } \\
\text { tercatat secara } \\
\text { konsisten } \\
\text { - Pengeluaran } \\
\text { operasional dan } \\
\text { pribadi masih } \\
\text { tergabung }\end{array}$ & $\begin{array}{l}\text { Peningkatan } \\
\text { teknik } \\
\text { administasi } \\
\text { melalui } \\
\text { penggunaan } \\
\text { aplikasi Point } \\
\text { of Sale (PoS) } \\
\text { berbasis } \\
\text { mobile }\end{array}$ \\
\hline 2 & $\begin{array}{l}\text { Kompete } \\
\text { nsi }\end{array}$ & $\begin{array}{l}\text { belum memahami } \\
\text { penggunaan aplikasi }\end{array}$ & $\begin{array}{l}\text { Kegiatan } \\
\text { pelatihan }\end{array}$ \\
\hline
\end{tabular}

\begin{tabular}{|l|l|l|l|}
\hline No & Bidang & Permasalahan & Solusi \\
\hline & sumber & PoS & penggunaan \\
& daya & & aplikasi PoS \\
& manusia & & berbasis \\
& mobile \\
\hline
\end{tabular}

\section{RUMUSAN MASALAH}

Permasalahan yang dihadapi oleh Tunjung Mekar dalam kegiatan pengabdian masyarakat adalah :

a. Permasalahan pada UKM Tunjung Mekar adalah proses pencatatan transaksi penjualan, yakni setiap ransaksi penjualan tidak dicatat oleh pemilik usaha. Bukti penjualan hanya dalam bentuk kertas atau bukti penjualan (kuitansi) yang mudah rusak dan mudah hilang. Selain itu pengeluaran operasional tidak tercatat dalam pengeluaran usaha. Permasalahan juga terdapat pada UKM di mana pengeluaran pribadi dan operasional belum tercatat secara terpisah. Permasalahan - permasalahan yang muncul ini berdampak pada alur keuangan yang berputar di UKM.

b. Pekerja dan pemilik usaha memiliki keterbatasan pengetahuan pemanfaatan aplikasi $P o S$ yang seharusnya dengan mudah dapat dimanfaatkan untuk menangani permasalahan administrasi pencatatan transaksi keuangan.

\section{METODE}

Metode yang digunakan pada kegiatan pengabdian ini adalah pelatihan: telah dilaksanakan pelatihan kepada UKM Tunjung Mekar untuk memanfaatkan aplikasi $P o S$ dalam pencatatan transaksi keuangan. Metode kedua yang digunakan pada kegiatan pengabdian yang dilakukan adalah substitusi ipteks: yakni dengan mengenalkan ipteks baru yang lebih modern dan efisien daripada ipteks lama (Chaffey ,2009), (Rudy, 2008), (Strauss, 2009). Ipteks yang dimasuk adalah aplikasi PoS (Point of Sale) sebagai aplikasi yang digunakan untuk mencatat transaksi keuangan dari UKM meliputi transaksi penjualan, transaksi pengeluaran untuk operasional, dan pelaporan keuangan. 
Untuk proses evaluasi kegiatan, metode yang digunakan adalah metode angket. Metode angket yang dilakukan adalah menilai setiap subproses kegiatan yang dilakukan oleh peserta dan menghasilkan penilaian kemampuan dari peserta, sehingga mampu menjadi nilai keberhasilan penilaian kegiatan pengabdian masyarakat.

\section{PEMBAHASAN}

A. Tahapan Pelaksanaan Kegiatan

Kegiatan pengabdian masyarakat yang dilakukan, memiliki tahap pelaksanaan. Tahap pelaksanaan ditunjukkan pada Gambar 3.

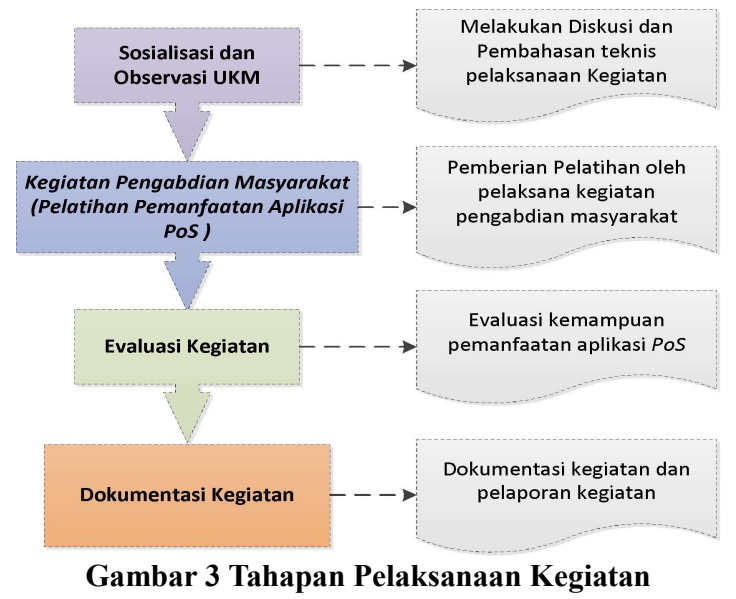

a. Sosialisasi dan Observasi UKM

Pada kegiatan sosialisasi dan observasi ini dilakukan diskusi dan pembahasan pelaksanaan teknis kegiatan dan kesepakatan penyusunan tanggal pelaksanaan kegiatan pengabdian,

b. Kegiatan Pengabdian Masyarakat: Pelatihan Pemanfaatan Aplikasi PoS Berbasis Mobile.

Pelaksanaan kegiatan ini diawali dengan acara pembukaan non-formal yang dihadiri oleh pihak pelaksana kegiatan yaitu dosen pelaksana dan mahasiswa dari ITB STIKOM Bali serta pihak UKM yaitu anak dari pemilik Usaha Tunjung Mekar. Setelah acara pembukaan secara non-formal dilakukan kegiatan pelatihan pemanfaatan aplikasi Point of Sale $(\mathrm{PoS})$ berbasis mobile. Kegiatan diawali dengan pengenalan fitur yang terdapat pada aplikasi, identifikasi PoS transaksi, penambahan produk dan detail produk dan pelaporan transaksi. Kemudian dilanjutkan dengan menginputkan data sesuai dengan masing masing $P o S$ dan fitur. Terakhir dilakukan pengecekan atau validasi data yang dimasukkan apakah sudah sesuai dengan data transaksi UKM.

c. Evaluasi Kegiatan

Evaluasi kegiatan dilakukan dilakukan dengan menguji dan memberikan pertanyaan kepada peserta mengenai teknis pencatatan transaksi pada aplikasi PoS. Hasilnya menunjukkan bahwa peserta mampu menggunakan aplikasi $P o S$ dengan penyerapan materi $82.5 \%$. Dan dari pelaksana kegiatan menyarankan agar penginputan data transaksi dilakukan seintensif mungkin untuk dapat digunakan dengan maksimal.

d. Dokumentasi Kegiatan

Dokumentasi yang dilakukan pada tahap akhir adalah proses pembuatan laporan kegiatan selama kegiatan berlangsung. Dokumentasi kegiatan dalam bentuk foto kegiatan juga dilampirkan dalam kegiatan dan pengisian data evaluasi dalam bentuk kuisioner evaluasi.

\section{B. Agenda Kegiatan Pengabdian}

Kegiatan penyuluhan pengabdian masyarakat dilakukan di UKM mitra Tunjung Mekar dapat ditunjukkan pada agenda kegiatan yang dapat dilihat pada Tabel 2.

Tabel 2. Agenda Kegiatan

\begin{tabular}{|c|l|l|c|}
\hline No & Tanggal & \multicolumn{1}{c|}{ Acara } & Durasi \\
\hline 1. & $\begin{array}{l}\text { 19 Oktober } \\
2019\end{array}$ & $\begin{array}{l}\text { Sosialisasi kegiatan } \\
\text { dan analisa situasi } \\
\text { keadaan di UKM } \\
\text { Tunjung Mekar }\end{array}$ & 90 Menit \\
\hline 2. & $\begin{array}{l}20 \\
\text { Nopember } \\
2019\end{array}$ & $\begin{array}{l}\text { Sosialisasi kegiatan } \\
\text { pengabdian } \\
\text { masyarakat berupa } \\
\text { informasi rencana } \\
\text { kegiatan }\end{array}$ & 60 Menit \\
\hline
\end{tabular}




\begin{tabular}{|c|c|c|c|}
\hline No & Tanggal & Acara & Durasi \\
\hline 3. & $\begin{array}{l}28 \text { Februari } \\
2020\end{array}$ & $\begin{array}{l}\text { Pelaksanaan } \\
\text { Pelatihan Kegiatan } \\
\text { Pengabdian } \\
\text { Masyarakat } \\
\text { - Acara Pembukaan } \\
\text { kegiatan (non- } \\
\text { formal) } \\
\text { - Pengenalan dasar } \\
\text { aplikasi } \\
\text { (Pengenalan fitur } \\
\text { dasar dan PoS } \\
\text { transaksi). } \\
\text { - Pelatihan } \\
\text { pemanfaatan } \\
\text { aplikasi } \\
\text { (penginputan data } \\
\text { transaksi } \\
\text { validasi data). } \\
\text { - Diskusi dan } \\
\text { jawab dari hasil } \\
\text { kegiatan } \\
\text { pengabdian } \\
\text { masyarakat } \\
\text { - Penutupan } \\
\text { kegiatan (non- } \\
\text { formal) }\end{array}$ & $\begin{array}{l}10 \text { Menit } \\
30 \text { menit } \\
120 \text { menit }\end{array}$ \\
\hline
\end{tabular}

C. Uraian Kegiatan Pengabdian

Kegiatan pengabdian masyarakat dilakukan pada tanggal 28 Februari 2020, diawali dengan acara pembukaan. Setelah acara pembukaan yang berlangsung selam 10 menit, dilanjutkan dengan kegiatan pengenalan dasar aplikasi $P o S$. Pengenalan fitur aplikasi dan $P o S$ transaksi seperti fitur Penjualan memiliki fungsi sebagai kasir memiliki PoS produk, $P O S$ jasa pengiriman. Fitur data produk memiliki $P o S$ produk, $P o S$ kategori dan stok produk. Fitur pengeluaran memiliki $P o S$ operasional bahan, operasional transportasi, operasional produksi dan $P o S$ pribadi. Fitur laporan memiliki $P o S$ pelaporan harian, mingguan bulanan dan tahunan.

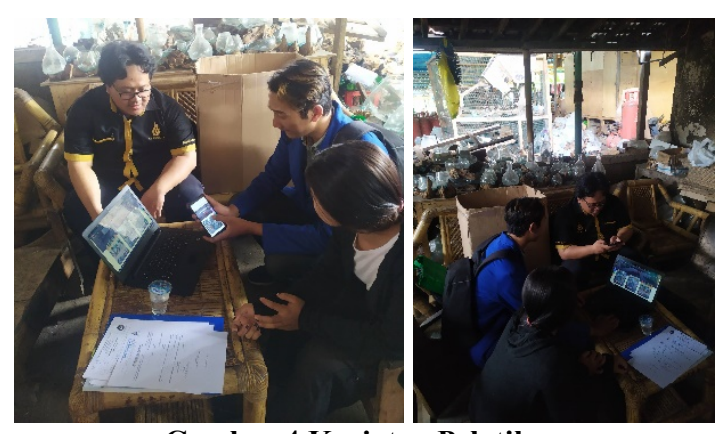

Gambar 4 Kegiatan Pelatihan
Setelah pengenalan fitur dasar aplikasi, dilakukan pelatihan pemanfaatan aplikasi $\operatorname{PoS}$ yaitu penginputan data sesuai dengan $P o S$ dan fitur pada aplikasi. Setiap data transaksi yang dimasukkan, diperiksa dan divalidasi sesuai dengan bukti fisik yang dimiliki (catatan kertas atupun bukti penjualan berupa kuitansi).

Setelah proses penginputan data dan validasi data dilakukan, dilanjutkan dengan kegiatan diskusi dan tanya jawab. Kegiatan ini diisi dengan tanya jawab mengenai teknis penggunaan aplikasi dan pengisian kuisioner kepuasan dan pemahaman penggunaan aplikasi.

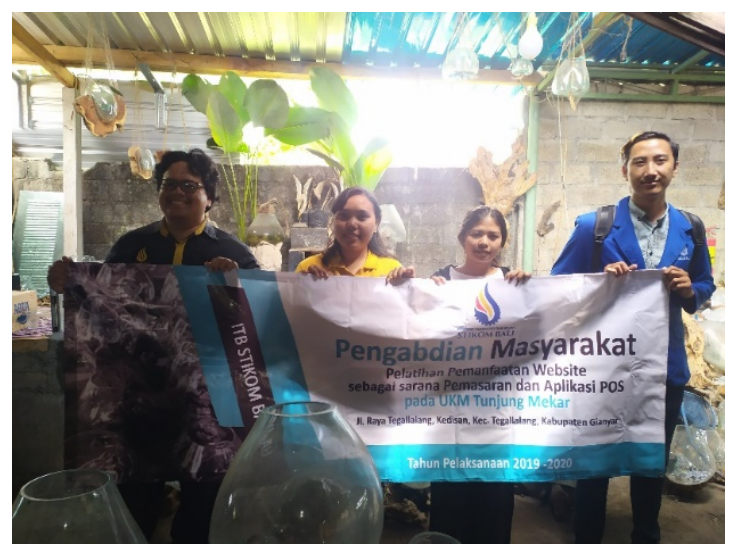

Gambar 5 Penutupan Kegiatan Pengabdian

Hasilnya dari kegiatan yang dilakukan menunjukkan bahwa peserta kegiatan pelatihan mampu menggunakan aplikasi dengan penyerapan materi $82.5 \%$. Adapun parameter yang digunakan untuk mengukur penyerapan dan kemampuan peserta pelatihan ditunjukkan pada Tabel 3.

\section{Produk Teknologi Tepat Guna} (Aplikasi PoS UKM Tunjung Mekar)

Aplikasi PoS UKM Tunjung Mekar berbasis mobile memiliki fitur transaksi penjualan, transaksi pengeluaran, data produk dan pelaporan. Aplikasi ini dirasa sangat membantu mengingat saat ini peserta pelatihan dari UKM telah terbiasa menggunakan smartphone mendukung dari aplikasi $P o S$ yang mampu berjalan di smartphone berbasis android, serta aplikasi 
PoS bersifat freeware. Antarmuka aplikasi $P o S$ ditujukkan pada Gambar 5.

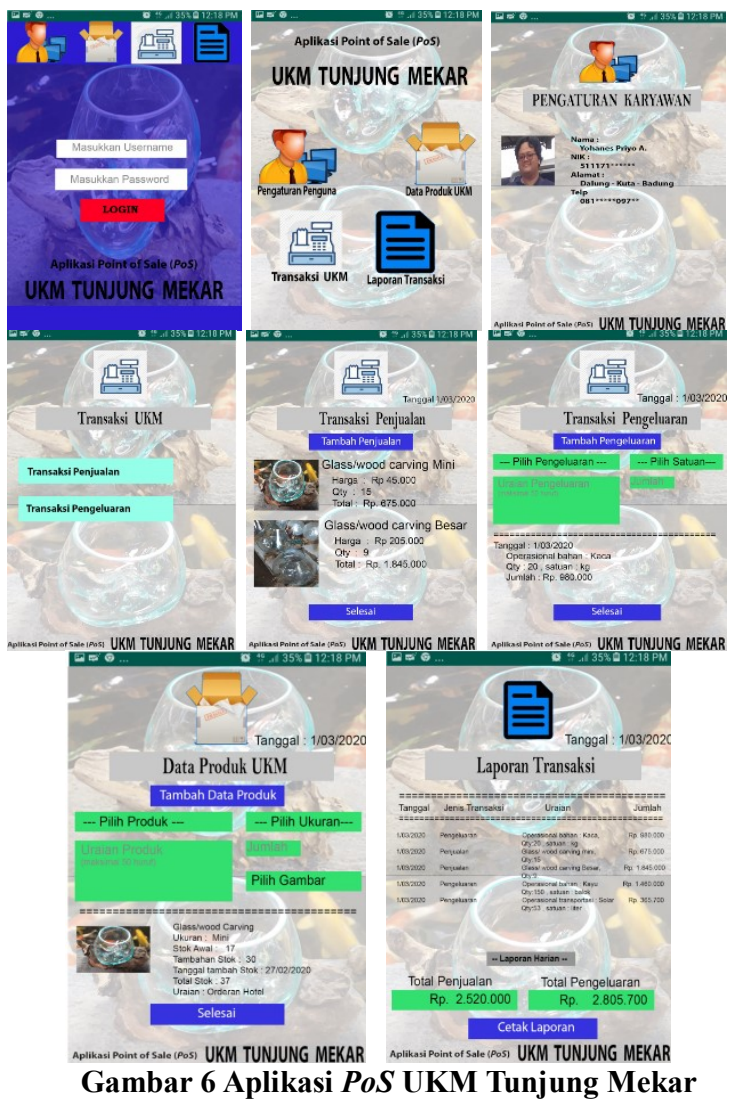

Transaksi penjualan merupakan fitur yang berfungsi untuk mencatat penjualan produk dan jasa pengiriman. Fitur pengeluaran berfungsi untuk mencatat pengeluaran usaha seperti pengeluaran operasional pembelian bahan, transportasi, operasional produksi dan pengeluaran pribadi. Fitur data produk berisikan detail produk UKM, dan jumlah stok produk. Fitur laporan berfungsi untuk informasi transaksi per periode yaitu harian, mingguan, bulanan dan tahunan.

\section{E. Evaluasi Kegiatan}

Pada kegiatan pengabdian masyarakat dilakukan proses evaluasi untuk melihat dan mengukur seberapa jauh keberhasilan pelaksanaan kegiatan yang telah dilaksanakan dengan cara mengukur kemampuan peserta terhadap pemahaman dan penggunaan alikasi yang telah diberikan setelah kegiaatan pelatihan. Evaluasi dilakukan dengan memberikan penilaian pemahaman dan kemampuan penggunaan oleh peserta berdasarkan parameter penilaian yang ditunjukkan pada Tabel 3.

Tabel 3. Parameter Penilaian Kemampuan

\begin{tabular}{|c|l|}
\hline No. & Parameter Penilaian \\
\hline 1 & Identifikasi PoS transaksi Pada UKM \\
\hline 2 & $\begin{array}{l}\text { Memilah } \text { PoS transaksi dari manual ke aplikasi } \\
P o S\end{array}$ \\
\hline 3 & $\begin{array}{l}\text { Mengakses atau membuka aplikasi } P o S \text { (Login } \\
\text { dengan username dan password UKM) }\end{array}$ \\
\hline 4 & $\begin{array}{l}\text { Memasukkan Nama Produk dan detail produk ke } \\
\text { aplikasi } \text { PoS }\end{array}$ \\
\hline 5 & Memasukkan data $P o S$ transaksi pemasukan \\
\hline 6 & Memasukkan data $P o S$ transaksi pengeluaran \\
\hline 7 & $\begin{array}{l}\text { Membuka laporan transaksi UKM pada Aplikasi } \\
\text { PoS }\end{array}$ \\
\hline 8 & Memperbaharui profil UKM pada aplikasi $P o S$ \\
\hline
\end{tabular}

Pada Tabel 3, terdapat parameter penilaian yang memiliki bobot penilaian antara lain STM (Sangat Tidak Mampu) = 10, TM (Tidak Mampu) $=20$, R (Raguragu $)=30, M(\mathrm{Mampu})=40$ dan $\mathrm{SM}$ (Sangat Mampu) $=50$. Untuk hasil penilaian STM dan TM dilakukan ulang pendampingan kegiatan pelatihan sehingga menghasilkan minial penilaian kemampuan peserta pada bobot R. Dari penilaian kemampuan menghasilkan nilai skor bobot dan persentase kemampuan peserta yang ditunjukkan pada Tabel 4 .

Tabel 4. Evaluasi Penilaian Kegiatan

\begin{tabular}{|c|c|c|c|c|c|c|}
\hline \multirow{2}{*}{ No } & \multirow{2}{*}{$\begin{array}{l}\text { Parameter } \\
\text { Penilaian }\end{array}$} & \multicolumn{5}{|c|}{ Penilaian } \\
\hline & & STM & TM & $\mathbf{R}$ & $\mathbf{M}$ & SM \\
\hline 1 & $\begin{array}{l}\text { Identifikasi } \\
\text { PoS transaksi } \\
\text { Pada UKM }\end{array}$ & & & & & 50 \\
\hline 2 & $\begin{array}{l}\text { Memilah } P o S \\
\text { transaksi dari } \\
\text { manual ke } \\
\text { aplikasi } P o S\end{array}$ & & & & 40 & \\
\hline 3 & $\begin{array}{l}\text { Mengakses } \\
\text { atau } \\
\text { membuka } \\
\text { aplikasi } P o S \\
\text { (Login } \\
\text { dengan } \\
\text { username dan } \\
\text { password } \\
\text { UKM) }\end{array}$ & & & & & 50 \\
\hline 4 & $\begin{array}{l}\text { Memasukkan } \\
\text { Nama Produk } \\
\text { dan detail } \\
\text { produk ke }\end{array}$ & & & 30 & & \\
\hline
\end{tabular}




\begin{tabular}{|c|c|c|c|c|c|c|}
\hline \multirow{2}{*}{ No } & \multirow{2}{*}{$\begin{array}{l}\text { Parameter } \\
\text { Penilaian }\end{array}$} & \multicolumn{5}{|c|}{ Penilaian } \\
\hline & & STM & $\mathbf{T M}$ & $\mathbf{R}$ & M & SM \\
\hline & aplikasi $P o S$ & & & & & \\
\hline 5 & $\begin{array}{l}\text { Memasukkan } \\
\text { data } P o S \\
\text { transaksi } \\
\text { pemasukan }\end{array}$ & & & & 40 & \\
\hline 6 & $\begin{array}{l}\text { Memasukkan } \\
\text { data } P o S \\
\text { transaksi } \\
\text { pengeluaran }\end{array}$ & & & & 40 & \\
\hline 7 & $\begin{array}{l}\text { Membuka } \\
\text { laporan } \\
\text { transaksi } \\
\text { UKM pada } \\
\text { Aplikasi } P o S\end{array}$ & & & & 40 & \\
\hline 8 & $\begin{array}{l}\text { Memperbahar } \\
\text { ui profil } \\
\text { UKM pada } \\
\text { aplikasi } P o S\end{array}$ & & & & 40 & \\
\hline \multicolumn{4}{|c|}{ Total Skor Bobot } & \multicolumn{3}{|c|}{330} \\
\hline \multicolumn{4}{|c|}{ Rata - Rata Skor } & \multicolumn{3}{|c|}{41.25} \\
\hline \multicolumn{4}{|c|}{ Persentase Skor } & \multicolumn{3}{|c|}{82.5} \\
\hline
\end{tabular}

Dari Tabel 4, dapat dilihat bahwa kegiatan ini memiliki pengukuran kemampuan dari peserta kegiatan dengan skor 330, dengan indikasi bobot pencapaian tertinggi adalah pada bobot 41.25 dengan persentase keberhasilan penguasaan, pemahaman dan kemampuan peserta kegiatan pada persentasi $82.5 \%$. Dengan nilai ambang keberhasilan $>=50$ $\%$ maka kegiatan ini dapat disimpulkan mencapai keberhasilan dengan kemampuan peserta adalah $82.5 \%$.

\section{SIMPULAN}

Kesimpulan dari hasil pelaksanaan pengadian masyarakat adalah:

1. Aplikasi $P o S$ berbasis mobile dapat diterapkan dan digunakan oleh UKM Tunjung Mekar dan mampu membantu UKM untuk melakukan pencatatan transaksi usaha UKM.

2. Peserta kegiatan pelatihan pemanfaatan aplikasi $\operatorname{PoS}$ berbasis mobile, mampu menggunakan aplikasi dengan daya penyerapan materi $82.5 \%$. Pengukuran penyerapan materi diperoleh dari hasil penilaian pemahaman, penyerapan dan kemampuan penggunaan aplikasi $P o S$ berdasarkan angket penilaian.
3. Kompetensi Sumber daya Manusia (pekerja) dari UKM mengalami peningkatan setelah pelaksanaan kegiatan pelatihan pemanfaatan aplikasi $P o S$. Dengan pemanfaatan aplikasi $P o S$ berbasis mobile, pekerja di UKM telah mengimplementasikan pemanfaatan teknologi informasi berbasis mobile.

Kegiatan berikutnya yang dapat digunakan sebagai perbaikan pada pelaksanaan pengabdian masyarakat adalah adanya penyempurnaan dan pengembangan fitur aplikasi $P o S$ berbasis mobile dan mengembangkan sisi akuntansi pada aplikasi.

\section{UCAPAN TERIMA KASIH}

Selama proses penyusunan jurnal pengabdian ini, penulis banyak memperoleh petunjuk dan bimbingan dari berbagai pihak. Sehubungan dengan hal tersebut pada kesempatan ini penulis menyampaikan ucapan terima kasih yang pertama pada Rektor dan Institusi Akademik yaitu Institut Teknologi dan Bisnis STIKOM Bali. Kedua ucapan terima kasih disampaikan kepada Fakultas Informatika dan Komputer Institut Teknologi dan Bisnis STIKOM Bali beserta jajaran struktural serta kolega yang telah memberikan kesempatan untuk melakukan kegiatan pengabdian masyarakat. Terima kasih juga disampaikan kepada semua pihak yang selalu memberikan dukungan secara langsung dan tidak langsung dalam penyelesaian jurnal pengabdian ini.

\section{DAFTAR PUSTAKA}

Abdurrahman, Shidiq, and Dwinita Larasati. (2013). Pemanfaatan Limbah Kaca Sebagai Bahan Baku Pengembangan Produk. Product Design, vol. 2, no. 1, 2013

Abednego, Stanley, and David Pramudita. (2017). "ANBOTTLE: Lampu Dekoratif dari Bahan Limbah Kayu dan Botol." Seminar Nasional Seni dan Desain 2017, Surabaya, 
Indonesia, October, 2017. State University of Surabaya, pp. 264-271.

Chaffey Dave, \& MayerRichard. (2009). Internet Marketing: Strategy, Implementation and Practice. Prentice Hall/Financial Times

Rudy. (2008). Perancangan E-Marketing pada PT. JEAH untuk Memenangkan Persaingan Usaha. Comtech. Vol 1 No. 2 Desember 2010:477-492.

Sunariani, N. N., Gorda, A. O. S., \& Mahaputra, I. I. R. (2017). Pemberdayaan Usaha Mikro Kecil Dan Menengah (UMKM) Melalui Program Binaan Di Provinsi Bali. Jurnal Ilmiah Manajemen Dan Bisnis, 2(1), 221-236.

Strauss, Judy., Frost, Raymond. (2009). EMarketing.(5th edition). New Jersey : Pearson Prentice Hall.

Tamara, P., \& Immanuel GultomP. (2016). Rancang Bangun Tungku Pelebur Limbah Kaca Untuk Sentra Ukm Manik-Manik Kaca. Industri Inovatif : Jurnal Teknik Industri, 6(1), 16-20. Dikutip dari URL : https://ejournal.itn.ac.id/index.php/in dustri/article/view/939. 